\title{
HOUSE FLY (MUSCA DOMESTICA) AS A TRANSPORT VECTOR OF CRYPTOSPORIDIUM PARVUM
}

\author{
Antonio Clavel, Olga Doiz, Santiago Morales, Marzo Varea, Cristina Seral, F. Javier Castillo, Jesús Fleta, \\ Carmen Rubio and Rafael Gómez-Lus
}

Departamento de Microbiología, Facultad de Medicina, Universidad de Zaragoza, c/ Domingo Miral s/n, 50009 Zaragoza, Spain

Synanthropic filth flies are a likely vehicle of transmission of human cryptosporidiosis. A polymerase chain reaction assay specific for the 18S rRNA gene of Cryptosporidium parvum Tyzzer, 1912 and C. wrairi Vetterling, Jervis, Merrill et Sprinz, 1971 was used for the direct detection of Cryptosporidium DNA in Musca domestica L. flies captured in two towns in Aragón (Spain). Six hundred flies were clustered in groups of ten and processed. An amplification product of the expected size ( 422 base pairs) was detected in 11 of the 60 groups $(18 \%)$.

Cryptosporidium parvum is an enteric coccidian parasite of mammals, including humans; it is frequently detected in young livestock. In humans, cryptosporidiosis is recognised as a common cause of acute transient diarrhoea. Transmission of oocysts excreted from infected hosts occurs either by direct host-to-host contact or indirectly by contaminated water or food; other indirect transmission mechanisms (for example arthropods) have not been sufficiently studied. Cryptosporidium parvum oocysts have been detected in flies, both captured in the wild (Sterling C.R., Miranda E., Gilman R.H. 1987: Am. J. Trop. Med. Hyg. 36 suppl: 233) and experimentally contaminated or caught in the very barn housing a Cryptosporidium-infected calf (Graczyk T.K., Cranfield M.R., Fayer R., Bixler H. 1999a: Am. J. Trop. Med. Hyg. 61: 500504; Graczyk T.K., Fayer R., Cranfield M.R., MhangamiRuwende B., Knight R., Trout J.M., Bixler H. 1999b: Emerg. Infect. Dis. 5: 726-727). It has been also identified in Periplaneta americana cockroaches (Zerpa R., Huicho L. 1994: Pediatric Infect. Dis. 13: 546-548), and in dung beetles (Mathison B.A., Ditrich O. 1999: J. Parasitol. 85: 678-81). Arthropods, and especially filth flies, could be a significant vehicle between faeces and food, especially in locations where contaminated faeces are readily accessible to them, as livestock-raising rural areas. It was the purpose of this work to detect possible Cryptosporidium parvum oocysts naturally occurring in flies in our geographical area.

In July and August, 1998, twenty adhesive fly traps were set outdoors in two towns in Aragón (north-eastern Spain) where livestock infection by Cryptosporidium was known to occur. Six hundred house flies (Musca domestica) captured in them were selected and crushed in a mortar in groups of ten; each group was resuspended separately in $4.5 \mathrm{ml}$ of PBS.

DNA was extracted as described elsewhere (Doiz O., Clavel A., Morales S., Varea M., Castillo F.J., Rubio C., Gómez-Lus R. 2000: Folia Parasitol. 47: 330-331). Briefly, oocysts were lysed by shaking them with $0.5-\mathrm{mm}$ zirconiasilica beads in a $10 \mathrm{M}$ guanidinium thiocyanate buffer; DNA was adsorbed on silica particles, purified with polyvinylpyrrolidone, and stored at $-20^{\circ} \mathrm{C}$ in TE buffer.
The primers selected for the PCR were CP3R (5'-GAG GGA CTT TGT ATG TTT AAT ACA GG-3') and the universal lower eukaryotic reverse primer B (5'-CCC GGG ATC CAA GCT TGA TCC TTC TGC AGG TTC ACC TAC3'), which delimitate a 422 base pairs fragment of the $18 \mathrm{~S}$ rRNA gene of $C$. parvum and C. wrairi (McLauchlin J., Pedraza-Díaz S., Amar-Hoetzeneder C., Nichols G.L. 1999: J. Clin. Microbiol. 37: 3153-3158). Primer CP3R corresponds to bases 1340 to 1365 and 1344 to 1369 of C. parvum sequences with GenBank accession Nos. L16996 and L16997, respectively, and 1340 to 1365 of the $C$. wrairi sequence with GenBank accession No. U11440 (McLauchlin et al. 1999, op. cit.). PCR amplification was performed in $25 \mu 1$ total volumes, which included $2.5 \mu 1$ of extracted target DNA in $1 \times$ PCR buffer, $1.5 \mathrm{mM} \mathrm{MgCl}_{2}, 0.1 \mathrm{mM}$ of dNTPs, $15 \mathrm{pM}$ of each primer, and 1.25 units of Taq DNA polymerase (Sigma). Tubes were subjected to 40 cycles of $90^{\circ} \mathrm{C}$ for $30 \mathrm{~s}, 65^{\circ} \mathrm{C}$ for 3 min, and $72^{\circ} \mathrm{C}$ for $3 \mathrm{~min}$, followed by a final extension at $72^{\circ} \mathrm{C}$ for $10 \mathrm{~min}$. Fifteen- $\mu \mathrm{l}$ aliquots of the PCR products were submitted to electrophoresis in $1.8 \%$ agarose/ethidium bromide gel and photographed using ultraviolet transillumination and Polaroid Type 52 film.

An amplification product of the expected size (422 base pairs) was detected in 11 of the 60 samples processed (18\%) (Fig. 1).

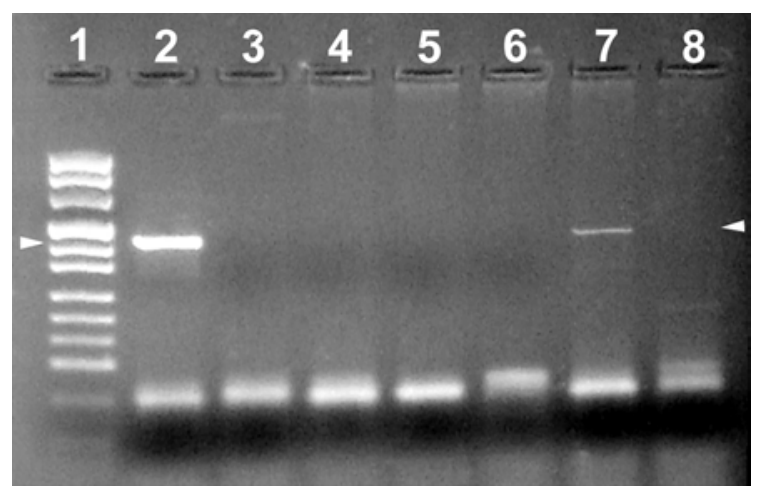

Fig. 1. Detection of the Cryptosporidium parvum 18S rRNA gene in house flies by PCR and ethidium bromide-stained $1.8 \%$ agarose gel electrophoresis. Arrowheads: 422 base pairs; lane 1: molecular weight marker; lane 2: positive control (positive human faecal sample); lanes 3-6: negative fly samples; lane 7: positive fly sample; lane 8: negative control (negative human faecal sample). 
It has been reported by Graczyk et al. (1999a, b, op. cit.) that flies breeding in or coming in contact with a faecal substrate contaminated with Cryptosporidium parvum oocysts harbour them both in their digestive tracts and on their external surfaces, and can deposit them via their excreta in substantial quantities $\left(108\right.$ oocysts $\left./ \mathrm{cm}^{2}\right)$. Flies could carry from 4 to 131 oocysts each for at least three weeks, and oocysts deposited by them were infectious for mice (Graczyk T.K., Fayer R., Knight R., Mhangami-Ruwende B., Trout J.M., Da Silva A.J., Pieniazek N.J. 2000: Am. J. Trop. Med. Hyg. 63: 178-83).

Given the low infective dose of Cryptosporidium, this poses an evident risk where flies may come in contact with a source of oocysts, livestock-raising areas being obvious candidates. A high prevalence of cryptosporidiosis in livestock has been found in Aragón, Spain: 19.7\% in cattle (Quílez J., Sánchez-Acedo C., del Cacho E., Clavel A., Causapé A.C 1996: Vet. Parasitol. 66: 139-146) and 20.7\% in sheep (Fleta J., Clavel A., Castillo J., Sánchez-Acedo C. 1991: Arch. Fac. Med. Zaragoza. 31: 45-49). Its prevalence is also high in other
European locations; e.g., $16.8 \%$ in calves in Switzerland (Lentze T., Hofer D., Gottstein B., Gaillard C., Busato A. 1999: Dtsch. Tieraerztl. Wochenschr. 106: 275-281). So, the presence of flies naturally harbouring Cryptosporidium oocysts, as reported here, is likely to be common in rural areas. Interestingly, the prevalence of human cryptosporidiosis at our hospital in Zaragoza over a period of 20 months was found to be significantly higher in patients from rural districts than in those of urban residence $(3.4 \%$ out of 675 patients compared to $1.2 \%$ out of $1429, \mathrm{p}<0.001$ ) (unpublished data). Although other transmission mechanisms (direct contact, waterborne) may be involved, the results of the present work suggest that the role of flies in the transmission of cryptosporidiosis is worth further consideration.

Acknowledgements. We thank L.M. Ortega-Mora (Facultad de Veterinaria, Universidad Complutense, Madrid) and S. Pedraza-Díaz (Food Hygiene Laboratory, PHLS, London) for their helpful suggestions. 